\title{
HUBUNGAN KADAR KOLESTEROL DARAH DENGAN BATU SALURAN KEMIH DI RUANG RAWAT INAP RSUD PROVINSI NTB
}

\author{
Ida Ayu Kadek Dewi Karyani ${ }^{1}$, Zaenal Arifin ${ }^{2}$, Melati Inayati Albayani ${ }^{3}$ \\ ${ }^{1)}$ Program Studi Ilmu Keperawatan STIKES Yarsi Mataram \\ ${ }^{2)}$ Program Studi Ners STIKES Yarsi Mataram \\ ${ }^{3)}$ Program Studi Keperawatan STIKES Yarsi Mataram \\ Email ;
}

\begin{abstract}
ABSTRAK
Batu saluran kemih merupakan masalah yang cukup besar karena penyakit ini banyak mengenai usia produktif. Salah satu faktor resiko terbentuknya BSK yaitu hiperkolesterolemia. Penelitian ini bertujuan untuk mengetahui hubungan antara kadar kolesterol total darah dengan BSK di ruang rawat inap RSUD Provinsi NTB 2018. Desain yang digunakan dalam penelitian ini adalah desain observasional analitik dengan pendekatan retrospektif.

Populasi dalam penelitian ini adalah responden BSK dan Non BSK. Sampel dalam penelitian ini sebanyak 66 responden dengan rincian terdiri dari 33 responden BSK dan 33 Non BSK (BPH). Dengan teknik sampel menggunakan simple random sampling. Penelitian ini dilakukan pada tanggal 28 Februari-3 Maret 2018. Alat pengumpulan data pada penelitian ini yaitu lembar check list. Analisis data menggunakan uji Chi-Square. Berdasarkan hasil penelitian diperoleh nilai p-value sebesar 0,013. Responden yang mempunyai kadar kolesterol total darah tinggi mempunyai peluang sebesar 4,1 kali terkena BSK dibandingkan dengan responden yang terkena non BSK/BPH (95\% CI OR 1,4:11,5). Dapat disimpulkan ada hubungan yang signifikan antara kadar kolesterol total darah dengan BSK di ruang rawat inap RSUD Provinsi NTB 2018. Rekomendasi yang dapat diberikan adalah kerjasama lintas program dengan instansi pelayanan kesehatan dalam rangka mengadakan promosi kesehatan dan konseling mengenai semua informasi yang berkenaan dengan BSK agar pasien lebih sadar dalam kesehatannya dan senantiasa memberikan pelayanan yang baik dan pengobatan yang tepat.
\end{abstract}

Kata Kunci : Kadar kolesterol total darah, BSK

\section{PENDAHULUAN}

Batu saluran kemih merupakan masalah yang cukup besar karena penyakit ini banyak mengenai usia produktif, batu saluran kemih banyak dijumpai pada orang dewasa antara umur 30-50 tahun, dan laki-laki tiga kali lebih banyak dibandingkan dengan perempuan (Purnomo, 2011). Terbentukya batu saluran kemih diduga karena ada hubungannya gangguan cairan urine, gangguan metabolik hiperkalsiuria, hiperkolesterolemia, infeksi saluran kemih, dehidrasi dan keadaan lain yang masih belum terungkap (idiopatik).

Secara epidemologis terdapat beberapa faktor yang mempermudah terjadinya BSK pada seseorang yaitu : faktor instrinsik: herediter, umur, jenis kelamin dan faktor ekstrinsik: kondisi geografis daerah, faktor lingkungan, jumlah air 
minum, diet, lama duduk saat bekerja, olahraga, obesitas, kebiasaan menahan buang air kemih dan konsumsi vitamin $\mathrm{C}$ dosis tinggi.

Hiperkolestrolemia akan disekresi melalui glomeorolus akan merangsang agregasi dengan kristal kalsium oksalat dan kalsium fosfat sehingga terbentuk batu. Kadar kolesterol yang tinggi akan di buang melalui glomerolus ginjal dan bercampur dengan air kemih, kolesterol yang didapat dari air kemih mengadakan ikatan dengan kristal-kristal yang larut dalam air sehingga menjadi BSK (Purnomo, 2011).

Batu saluran kemih merupakan masalah yang cukup besar karena penyakit ini banyak mengenai usia produktif, batu saluran kemih banyak dijumpai pada orang dewasa antara umur 30-50 tahun, dan laki-laki tiga kali lebih banyak dibandingkan dengan perempuan (Purnomo, 2011). Data America Urologic Association (AUA) pada tahun 2007 menunjukan bahwa di Amerika Serikat $5-10 \%$ penduduknya menderita penyakit batu saluran kemih, sedangkan di seluruh dunia rata-rata terdapat 1-12\% penduduk dunia menderita penyakit ini.

Data Riskesdas (2013) menunjukkan prevalensi penyakit batu saluran kemih di Indonesia meningkat seiring dengan bertambahnya usia. Secara nasional prevalensi batu saluran kemih adalah $0,6 \%$. Tertinggi pada kelompok umur 55-64 tahun (1,3\%), menurun sedikit pada kelompok umur 65-74 tahun $(1,2 \%)$ dan umur $\geq 75$ tahun $(1,1 \%)$. Prevalensinya lebih tinggi pada laki-laki $(0,8 \%)$ dan perempuan $(0,4 \%)$. Angka kejadian batu ginjal di Indonesia adalah 37.636 kasus baru dengan jumlah kunjungan 58.959 orang. Sedangkan jumlah pasien yang dirawat 19.018 orang, dengan jumlah kematian 378 orang.

Kejadian batu saluran kemih di RSUD Provinsi NTB masih cukup tinggi. Hal ini dapat dilihat dari rekapitulasi laporan penyakit batu saluran kemih di RSUD Provinsi NTB tahun 2014 sebanyak 692 meningkat di tahun 2015 sebanyak 793 dan di tahun 2016 sebanyak 851 orang (Data RSUD Provinsi NTB, 2016)

Dampak dari BSK yang tidak segera mendapatkan terapi yg adekuat menyebabkan komplikasi. Komplikasi yang paling sering adalah berupa infeksi saluran kemih sebagai akibat adanya statis urin oleh adanya batu sampai terjadinya penurunan fungsi ginjal, yang dapat berlanjut sampai gagal ginjal terminal. Fungsi ginjal sangat dipengaruhi oleh adanya berbagai faktor resiko yang disertai penyakit dasar seperti: Diabetes Melitus, Hipertensi, merokok dan disiplidemia. Displidemia yang utama pada penderita adalah meningkatnya kadar trigliserida, kolesterol dan lipida total yang disebabkan karena kurang berfungsinya Lipoprotein Lipase (LpL) dan Hepatik Trigliserid Lipase (Kimata, 2012).

Solusi yang dapat dilakukan untuk mencegah meningkatnya kadar kolesterol darah adalah dengan mengkonsumsi makanan seimbang sesuai kebutuhan, menghindari lemak jenuh, meningkatkan konsumsi lemak tak jenuh, penurunan berat badan dengan olahraga dan perubahan pola makan, menghentikan kebiasaan merokok dan olah raga teratur (Sutanto, 2010).

Berdasarkan Studi pendahuluan yang dilakukan oleh peneliti terhadap 6 orang pasien pada tanggal 13 November 2017 diruang rawat Inap di RSUD Provinsi NTB di dapatkan data bahwa 3 pasien BSK memiliki kadar kolesterol total tinggi, yaitu $\geq 240 \mathrm{mg} / \mathrm{dl}$ bahkan ada yang mencapai $300 \mathrm{mg} / \mathrm{dl}$, dan 2 pasien memiliki kadar kolesterol borderline (sedikit tinggi) yaitu antara 200-230 $\mathrm{mg} / \mathrm{dl}$, sisanya 1 pasien memiliki kadar kolesterol normal, yaitu $<200 \mathrm{mg} / \mathrm{dl}$. Didapatkan riwayat keluhan sebelumnya 
yang sering dirasakan pada pasien kadar kolesterol tinggi dan sedikit tinggi yaitu sering pusing di kepala belakang, tengkuk dan pundak terasa pegal, kesemutan di tangan dan kaki bahkan ada yang mengeluhkan dada disebelah kiri terasa nyeri seperti tertusuk-tusuk, tetapi tidak pernah diperiksakan ke dokter atau pelayanan kesehatan sebelumnya.

Penelitian Husnah tahun 2015 menyatakan terdapat hubungan antara kadar kolesterol darah dengan kejadian batu saluran kemih, Kadar kolesterol darah tinggi 6,8 kali berisiko terjadinya batu saluran kemih. Penelitian Satoshi et al tahun 2005 menyatakan terdapat hubungan antara kadar kolesterol darah dengan BSK dengan kecenderungan seseorang yang mempunyai kadar kolesterol tinggi punya resiko 3 kali untuk menderita BSK dibandingkan dengan orang yang kadar kolesterolnya normal. Berdasarkan hasil penelitian ini dapat terlihat kadar kolesterol darah merupakan faktor indikator penting dalam pengendalian BSK, Untuk itu pemeriksaan kadar kolesterol darah penting dilakukan untuk mencegah kejadian BSK sehingga penderita dapat mempertahankan kualitas hidupnya. Berdasarkan uraian di atas, maka peneliti tertarik untuk melakukan penelitian tentang hubungan antara kadar kolesterol darah dengan batu saluran kemih di ruang rawat inap di RSUD Provinsi NTB.

\section{METODOLOGI PENELITIAN}

Penelitian ini merupakan jenis penelitian observasional analitik dengan pendekatan retrospektif, desain penelitian ini disebut juga dengan desain case-control, yaitu pengamatan dan penilaian sampel dilakukan terlebih dahulu untuk kemudian ditelusuri faktor resiko atau penyebab yang telah terjadi dimasa lalu. Data yang dikumpulkan berasal dari data kejadian yang berlalu. Metode pengumpulan data yang dipakai dengan metode documentary-historical yaitu mengumpulkan data dari berbagai catatan keperawatan pasien yang telah berlalu (Suyanto, 2011). Penelitian ini telah dilakukan pada tanggal 28 Februari-3 Maret 2018 di ruang rawat inap RSUD Provinsi NTB. Menurut Arikunto (2010), populasi adalah keseluruhan objek yang diteliti. Terdapat dua jenis populasi dalam penelitian ini, yaitu populasi penelitian dan populasi kontrol. Populasi penelitian yang digunakan dalam penelitian ini adalah seluruh pasien dengan BSK di ruang rawat inap RSUD Provinsi NTB dalam kurun waktu dari bulan OktoberDesember 2017 di ruang rawat inap RSUD Provinsi NTB yang berjumlah rata-rata 97 orang dan populasi kontrol pada penelitian ini adalah pasien Non BSK yaitu 34 orang. Sampel adalah sebagian dari keseluruhan obyek yang diteliti dan dianggap mewakili seluruh populasi (Notoatmodjo, 2012). Teknik pengambilan sampel disebut juga teknik sampling. Teknik sampling yang digunakan dalam sampling ini adalah probability sampling dengan pengambilan secara acak (simple random sampling). Menurut Sugiyono (2012), probability sampling adalah teknik pengambilan sampel yang memberikan peluang yang sama bagi setiap unsur (anggota) populasi untuk dipilih menjadi anggota sampel. Dalam hal ini setiap anggota populasi memiliki kesempatan yang sama untuk dijadikan sampel. Sedangkan simple random sampling dikatakan sederhana karena pengambilan anggota sampel dari populasi dilakukan secara acak tanpa memperhatikan strata yang ada dalam populasi itu. Pengambilan sampel harus dilakukan sedemikian rupa sehingga diperoleh sampel yang benar-benar dapat 
mewakili dan dapat menggambarkan keadaan populasi yang sebenarnya, maka dalam penentuan besar sampel ditentukan berdasarkan rumus analitik komparatif kategorikal tidak berpasangan (Dahlan, 2010). Sampel yang digunakan dalam penilitian ini adalah seluruh pasien yang terdiri dari pasien dengan BSK berjumlah 33 orang dan pasien yang Non BSK dengan jumlah yang sama yaitu 33 orang.

\section{HASIL PENELITIAN}

\subsection{Karakteristik Responden \\ Demografi}

Hasil indentifikasi karakteristik responden di ruang rekam medis RSUD Provinsi NTB yang meliputi umur, jenis kelamin, pendidikan dan pekerjaan akan diuraikan dalam bentuk tabel sebagai berikut:

Tabel 3.1 Distribusi Frekuensi Responden Berdasarkan Umur, Jenis Kelamin, Tingkat Pendidikan dan Jenis Pekerjaan di Ruang Rawat Inap RSUD Provinsi NTB Tahun 2018, dapat di lihat pada tabel di bawah ini:

\begin{tabular}{|l|c|c|c|c|c|c|}
\hline \multirow{2}{*}{$\begin{array}{c}\text { Karakteristik } \\
\text { Responden }\end{array}$} & \multicolumn{2}{|c|}{$\begin{array}{c}\text { Penelitian } \\
\text { (BSK) }\end{array}$} & $\begin{array}{c}\text { Kontrol (Non- } \\
\text { BSK / BPH) }\end{array}$ & \multicolumn{2}{|c|}{ Total } \\
\cline { 2 - 7 } Nelompok Umur & & & N & \% & N & $\%$ \\
\hline 30 & 3 & 9,1 & - & - & 3 & 4,55 \\
$30-50$ & 20 & 60,6 & 5 & 15,2 & 25 & 37,9 \\
P50 & 10 & 30,3 & 28 & 84,8 & 38 & 57,55 \\
Jenis Kelamin & & & & & & \\
Laki-Laki & 21 & 63,6 & 33 & 100 & 54 & 81.8 \\
Perempuan & 12 & 36,4 & - & - & 12 & 18,2 \\
Tingkat & & & & & & \\
Pendidikan & 7 & 21,2 & 5 & 15,2 & 12 & 18,2 \\
SD & 6 & 18,2 & 4 & 12,1 & 37 & 15,15 \\
SMP & 16 & 58,5 & 21 & 63,6 & 7 & 56,05 \\
SMA & 4 & 12,1 & 3 & 9,1 & & 10,6 \\
PT & & & & & 19 & \\
Jenis Pekerjaan & 9 & 27,3 & 10 & 30,3 & 18 & 28,8 \\
Petani & 14 & 42,4 & 4 & 12,1 & 13 & 27,25 \\
Swasta & 7 & 21,2 & 6 & 18,2 & 16 & 19,7 \\
PNS & 3 & 9,1 & 13 & 39,4 & & 24,2 \\
Pensiunan & 33 & 100 & 33 & 100 & 66 & 100 \\
\hline \multicolumn{1}{|c|}{ Jumlah } & & & & & \\
\hline
\end{tabular}

Berdasarkan tabel di atas, dapat diketahui bahwa sebagian besar responden pada BSK (kelompok penelitian) berumur 30-50 tahun yaitu sebanyak 20 orang $(60,6 \%)$ dan sebagian kecil berumur <30 tahun sebanyak 3 orang $(9,1 \%)$. Sedangkan responden pada non BSK/BPH (kelompok kontrol) sebagian besar responden berumur > 50 tahun yaitu sebanyak 28 orang $(84,8)$ dan sebagian kecil berumur 30-50 tahun sebanyak 5 orang (15,2\%).

Berdasarkan tabel di atas, dapat diketahui bahwa sebagian besar responden pada BSK (kelompok penelitian) mempunyai jenis kelamin laki-laki yaitu sebanyak 21 orang $(63,6 \%)$ dan sebagian kecil mempunyai jenis kelamin perempuan sebanyak 12 orang $(36,4 \%)$. Sedangkan responden pada non BSK/BPH (kelompok kontrol) keseluruhan mempunyai jenis kelamin laki-laki yaitu sebanyak 33 orang (100\%).

Berdasarkan tabel di atas, dapat diketahui bahwa sebagian besar responden pada BSK (kelompok penelitian) berpendidikan SMA yaitu sebanyak 16 orang $(48,5 \%)$ dan sebagian kecil berpendidikan PT sebanyak 4 orang $(12,1 \%)$. Sedangkan responden pada non BSK/BPH (kelompok kontrol) sebagian besar berpendidikan SMA yaitu sebanyak 21 orang $(63,6 \%)$ dan sebagian kecil berpendidikan PT yaitu sebanyak 3 orang $(9,1 \%)$. Berdasarkan tabel di atas, dapat diketahui bahwa sebagian besar responden pada BSK (kelompok penelitian) mempunyai pekerjaan swasta yaitu sebanyak 14 orang $(42,4 \%)$ dan sebagian kecil mempunyai pekerjaan sebagai pensiunan sebanyak 3 orang $(9,1 \%)$. Sedangkan responden pada non BSK/BPH (kelompok kontrol) sebagian besar sebagai pensiunan 
yaitu sebanyak 13 orang $(39,4 \%)$ dan sebagian kecil mempunyai pekerjaan swasta yaitu sebanyak 4 orang $(12,1 \%)$.

\subsection{Variabel yang diukur}

\subsubsection{Kadar Kolesterol Total Darah Responden dengan BSK}

Tabel 3.2 Distribusi Frekuensi Responden Berdasarkan Kadar Kolesterol Total Darah Responden dengan BSK di Ruang Rawat Inap RSUD Provinsi NTB Tahun 2018, dapat di lihat pada tabel di bawah ini:

\begin{tabular}{|l|c|c|c|c|}
\hline \multirow{2}{*}{ Kadar Kolesterol } & \multicolumn{2}{|c|}{$\begin{array}{c}\text { Penelitian } \\
\text { (BSK) }\end{array}$} & \multicolumn{2}{c|}{ Total } \\
\cline { 2 - 5 } & $\mathbf{N}$ & \% & N & $\%$ \\
\hline Normal & 9 & 27,3 & 9 & 27,3 \\
Tinggi & 24 & 72,7 & 24 & 72,7 \\
\hline \multicolumn{1}{|c|}{ Jumlah } & 33 & 100 & 33 & 100 \\
\hline
\end{tabular}

Berdasarkan tabel di atas, dapat diketahui bahwa sebagian besar responden mempunyai kadar kolesterol total darah tinggi yaitu sebanyak 24 orang $(72,7 \%)$ adalah pada BSK (kelompok penelitian), sedangkan yang mempunyai kadar kolesterol total darah normal yaitu sebanyak 9 orang $(27,3 \%)$.

\subsubsection{Kadar Kolesterol Total Darah Responden dengan Non BSK}

Tabel 3.3 Distribusi Frekuensi Responden Berdasarkan Kadar Kolesterol Total Darah Responden dengan Non BSK di Ruang Rawat Inap RSUD Provinsi NTB Tahun 2018, dapat di lihat pada tabel di bawah ini:

\begin{tabular}{|l|c|c|c|c|}
\hline \multirow{2}{*}{ Kadar Kolesterol } & \multicolumn{2}{|c|}{$\begin{array}{c}\text { Penelitian } \\
\text { (BSK) }\end{array}$} & \multicolumn{2}{c|}{ Total } \\
\cline { 2 - 5 } & N & $\%$ & N & $\%$ \\
\hline Normal & 20 & 60,6 & 20 & 60,6 \\
Tinggi & 13 & 39,4 & 13 & 39,4 \\
\hline \multicolumn{1}{|c|}{ Jumlah } & 33 & 100 & 33 & 100 \\
\hline
\end{tabular}

Berdasarkan tabel diatas, dapat diketahui bahwa sebagian besar responden pada non BSK mempunyai kadar kolesterol total darah normal sebanyak 20 orang $(60,6 \%)$ sedangkan responden yang mempunyai kadar kolesterol total darah tinggi sebanyak 13 orang $(39,4 \%)$.

\subsubsection{Hubungan Antara Kadar Kolesterol Total Darah dengan BSK}

Tabel 3.4 Tabulasi Silang Kadar Kolesterol Total Darah dengan BSK di Ruang Rawat Inap RSUD Provinsi NTB Tahun 2018, dapat di lihat pada tabel di bawah ini:

\begin{tabular}{|c|c|c|c|c|c|c|c|c|c|}
\hline \multirow{3}{*}{$\begin{array}{c}\text { Kadar } \\
\text { Kolestrol } \\
\text { Darah }\end{array}$} & \multicolumn{4}{|c|}{ Pasien } & \multirow{2}{*}{\multicolumn{2}{|c|}{ Total }} & \multirow{3}{*}{$\mathbf{X}^{2}$} & \multirow{3}{*}{$\begin{array}{c}\text { OR } \\
(95 \\
\% \text { CI } \\
)\end{array}$} & \multirow{3}{*}{$\begin{array}{c}\text { P- } \\
\text { value }\end{array}$} \\
\hline & \multicolumn{2}{|c|}{ BSK } & \multicolumn{2}{|c|}{$\begin{array}{c}\text { Non- } \\
\text { BSK/BPH }\end{array}$} & & & & & \\
\hline & $\mathbf{N}$ & $\%$ & $\mathbf{N}$ & $\%$ & $\mathbf{N}$ & $\%$ & & & \\
\hline Normal & 9 & 27,3 & 20 & 60,6 & 29 & 43,9 & 8232 & 4,1 & 0012 \\
\hline Tinggi & 24 & 72,7 & 13 & 39,4 & 37 & 56,1 & 8,334 & $\begin{array}{l}(1,4- \\
11,5)\end{array}$ & 0,013 \\
\hline Total & 33 & 100 & 33 & 100 & 66 & 100 & & & \\
\hline
\end{tabular}

Berdasarkan tabel di atas, didapatkan sebesar $72,7 \%$ dari kelompok responden yang terkena BSK (kelompok penelitian) adalah responden yang mempunyai kadar kolesterol total darah tinggi. Sisanya sebesar $27,3 \%$ adalah responden yang mempunyai kadar kolesterol total darah normal. Sedangkan responden pada non BSK/BPH (kelompok kontrol) proporsi yang mempunyai kadar kolesterol total tinggi lebih kecil yaitu sebesar 39,4\%, sisanya sebesar $60,6 \%$ adalah mempunyai kadar kolesterol total normal. Analisis lanjut menyimpulkan bahwa terdapat hubungan yang signifikan atau bermakna antara kadar kolesterol total darah dengan BSK (p-value sebesar 0,013). Responden yang mempunyai kadar kolesterol darah tinggi mempunyai peluang sebesar 4,1 kali terkena BSK dibandingkan dengan responden yang terkena non BSK/BPH (95\% CI OR 1,4;11,5). 


\section{PEMBAHASAN}

Berdasarkan hasil penelitian, dapat diketahui bahwa sebagian besar responden pada BSK (kelompok penelitian) banyak mengenai usia 30-50 tahun. Usia produktif tersebut merupakan salah satu faktor resiko terjadinya BSK (Purnomo, 2011). Menurut peneliti hal ini disebabkan oleh life style seperti seseorang biasanya akan lupa untuk minum apabila bekerja di ruangan yang sejuk. Selain itu konsumsi makanan tidak sehat dan kelainan metabolisme tubuh juga dapat menjadi penyebab lainnya, yang dapat menyebabkan urin menjadi pekat sehingga terjadi perkristalan didalam saluran kemih sesuai dengan teori Purnomo. Menurut teori Purnomo (2011), penyebab dan patologis pembentukan BSK yaitu salah satunya teori vaskuler (hipertensi dan kolesterol). Sedangkan pada non BSK/BPH mengenai umur $\geq 50$ tahun. Menurut Cooperberg (2013) menyebutkan bahwa $\pm 25 \%$ laki-laki mengeluh gejala obstruksi pada saluran kemih bagian bawah, meningkat hingga umur 75 tahun, dimana $50 \%$ mengeluh berkurangnya pancaran/aliran pada saat berkemih.

Menurut peneliti penyebab non BSK/BPH berhubungan dengan proses penuaan yang mengakibatkan kelemahan pada buli (otot destrusor), penurunan fungsi persarafan, dan penurunan kadar hormon pria, terutama testosteron. Hal ini sesuai dengan penelitian Amit Gupta, dkk (2006), mengenai faktor atropometri dan metabolisme dan resiko dari $\mathrm{BPH}$. Hasil penelitian menyatakan ada peningkatan risiko BPH dengan meningkatnya umur, dan ukuran tinggi tubuh. Menurut Cooperberg (2013) adanya hormon testosteron dalam kelenjar prostat akan dirubah menjadi DHT yang kemudian secara kronis merangsang kelenjar prostat sehingga membesar.

Berdasarkan hasil penelitian, dapat diketahui bahwa sebagian besar responden pada BSK (kelompok Penelitian) mempunyai jenis kelamin laki - laki. Menurut Purnomo (2011) laki-laki tiga kali lebih banyak menderita BSK dibandingkan dengan perempuan.

Menurut peneliti BSK sering terjadi pada laki-laki daripada perempuan karena saluran kemih pada laki-laki lebih sempit daripada perempuan sehingga menyebabkan masalah dan juga karena adanya pengaruh hormon, pada laki-laki hormon testosteron yang tinggi memudahkan kristalisasi dan terjadi BSK. Sedangkan pada perempuan hormonnya dapat menghambat pertumbuhan BSK meskipun tidak seratus persen. Hal ini sesuai dengan teori Purnomo. Menurut Purnomo (2011) menyatakan bahwa serum testosteron menghasilkan peningkatan produksi oksalat endogen oleh hati. Pada wanita memiliki inhibitor seperti pengeluaran kalsium dibandingkan laki-laki secara alami menyebabkan rendahnya kejadian BSK.

Sedangkan responden pada non BSK/BPH (kelompok kontrol) keseluruhan mempunyai jenis kelamin laki-laki. Prostat adalah organ genetalia laki-laki yang terletak di bawah buli-buli di depan rektum dan membungkus uretra posterior. BPH merupakan penyakit yang biasa terjadi pada laki-laki usia lanjut, ditandai dengan pertumbuhan yang sangat cepat pada epitel prostat dan daerah transisi fibromuscular pada daerah periurethal yang bisa menghalangi dan mengakibatkan pengeluaran urin yang tertahan (Purnomo, 2011).

Menurut peneliti, kelenjar prostat sangat penting bagi laki-laki karena berfungsi untuk mengeluarkan dan menyimpan sejenis cairan yang menjadi dua pertiga 
bagian dari air mani, sehingga saluran uretra terjaga kelembabannya, tetapi jika produksi kelenjar prostat membesar dengan cepat/tidak stabil akan mendesak uretra yang mengakibatkan rasa tidak nyaman pada penderita. Hal ini di dukung oleh Purnomo (2011), menyatakan bahwa kelenjar prostat memproduksi cairan seminal dan sekresi lain yang membuat saluran uretra terjaga kelembabannya dan peningkatan 5 alfa reduktase dan reseptor androgen menyebabakan epitel dan stoma dari kelenjar prostat mengalami hiperplasia.

Berdasarkan hasil penelitian, dapat diketahui bahwa sebagian besar responden pada BSK (kelompok Penelitian) berpendidikan SMA yaitu sebanyak 16 orang $(48,5 \%)$ dan sebagian kecil berpendidikan PT sebanyak 4 orang $(12,1 \%)$. Sedangkan responden pada non BSK/BPH (kelompok kontrol) sebagian besar berpendidikan SMA yaitu sebanyak 21 orang $(63,6 \%)$ dan sebagian kecil berpendidikan PT yaitu sebanyak 3 orang $(9,1 \%)$.

Menurut Notoatmojo (2007), tingkat pendidikan seseorang akan membantu orang tersebut untuk lebih mudah menangkap dan memahami suatu informasi. Individu dengan tingkat pendidikan tinggi memiliki kualitas hidup yang lebih tinggi dibanding dengan berpendidikan rendah, dimana nilai yang rendah umumnya terletak pada komponen peran fisik dan peran mental (Abdurachim, 2007). Menurut peneliti, masih adanya yang terkena BSK dan non BSK/BPH, ini dikarenakan kurangnya komponen peran fisik yaitu jika di lihat dari segi aktivitas seharihari dan mobilitas yang kurang, berkaitan dengan pekerjaan responden penelitian.

Berdasarkan hasil penelitian, dapat diketahui bahwa sebagian besar responden pada BSK (kelompok penelitian) mempunyai pekerjaan swasta yaitu sebanyak 14 orang $(42,4 \%)$ dan sebagian kecil mempunyai pekerjaan sebagai pensiunan sebanyak 3 orang $(9,1 \%)$. Kejadian BSK lebih banyak terjadi pada pegawai swasta (administrasi/sopir/pedagang/penjahit) dan orang-orang yang banyak duduk dalam melakukan pekerjaannya dapat mengganggu proses metabolisme tubuh. (Purnomo, 2011).

Menurut peneliti, pasien yang terlalu banyak duduk atau hanya ditempat tidur saja, maka kalsium tulang akan dilepas ke darah, selanjutnya hiperkalsemia akan memacu timbulnya BSK karena adanya supersaturasi elektrolit/kristal dalam air kemih. Hal ini sesuai dengan teori Purnomo. Pada teori Purnomo (2011) menyatakan bahwa supersaturasi bisa juga dipengaruhi PH dan suhu air kemih. Kenaikan konsentrasi bahan pembentuk batu didalam tubulus renalis akan merubah zona stabil saturasi rendah menjadi zona supersaturasi metastabil dan bila konsentrasinya makin tinggi menjadi zona saturasi tinggi.

Sedangkan responden pada non BSK/BPH (kelompok kontrol) sebagian besar sebagai pensiunan yaitu sebanyak 13 orang $(39,4 \%)$ dan sebagian kecil mempunyai pekerjaan swasta yaitu sebanyak 4 orang $(12,1 \%)$. Pada $\mathrm{BPH}$ lebih banyak pada pensiunan, hal ini sering dikaitkan dengan faktor usia. Hampir semua pensiunan adalah yang berusia lanjut, dimana semakin tinggi usia juga semakin tinggi kejadian $\mathrm{BPH}$ (Cooperberg, 2013).

Menurut peneliti pengaruh usia berkaitan dengan bertambahnya volume prostat terhadap skor gejala serta terjadinya remodeling jaringan- jaringan di dalam kelenjar prostat. Hal ini sesuai teori Purnomo. Purnomo (2011) menyatakan bahwa seiring bertambahnya usia terjadi ketidakseimbangan antara hormon estrogen-testosteron, interaksi antara sel stroma-epitel, dan growth factor yang 
memicu pertumbuhan sel-sel kelenjar prostat.

Berdasarkan hasil penelitian, dapat diketahui bahwa responden yang terkena BSK sebagian besar disebabkan karena kadar kolesterol total darah tinggi (Purnomo, 2011). Dimana pada kelompok responden yang mempunyai kadar kolesterol total darah tinggi sebanyak 24 orang $(72,7 \%)$ terkena BSK. Oleh karena RSUD Provinsi NTB adalah salah satu Rumah Sakit Rujukan sehingga banyaknya pelayananpelayanan kesehatan di Pulau Sumbawa, Bima dan Kabupaten/Kota yang ada di Provinsi NTB, yang cukup sering melakukan rujukan terutama pada kasuskasus dengan Urulogi dan komplikasi nya, salah satunya adalah BSK dimana kasus tersebut harus ditangani di lingkup Rumah Sakit yang memilki fasilitas yang lengkap dan tenaga medis yang berkompeten. RSUD Provinsi NTB memiliki fasilitas yang lengkap serta tenaga medis dan tenaga kesehatan dalam menghadapi BSK dengan penyulit.

Menurut Purnomo (2011) Secara epidemologis terdapat beberapa faktor yang mempermudah terjadinya BSK pada seseorang yaitu: faktor instrinsik: herediter, umur, jenis kelamin dan faktor ekstrinsik: kondisi geografis daerah, faktor lingkungan, jumlah air minum, diet, lama duduk saat bekerja, olahraga, obesitas, kebiasaan menahan buang air kemih dan konsumsi vitamin $\mathrm{C}$ dosis tinggi.

Menurut peneliti ketika seseorang mengkonsumsi lemak berlebihan, akan banyak kolesterol jahat yang menyangkut di dinding pembuluh darah, dan tidak ada kolesterol baik yang akan melepaskannya, maka oksalat yang diresorbsi menjadi lebih banyak sehingga mengakibatkan terbentuknya batu saluran kemih. Hal ini sesuai teori Purnomo (2011), menyatakan bahwa kolesterol yang terdapat dalam air kemih akan mengadakan ikatan dengan kristalkristal yang larut dalam air kemih sehingga menjadi BSK (Purnomo, 2011).

Kadar kolesterol total darah tinggi dapat menyebabkan berbagai komplikasi. Komplikasi yang paling sering adalah berupa infeksi saluran kemih sebagai akibat adanya statis urin oleh adanya batu sampai terjadinya penurunan fungsi ginjal, yang dapat berlanjut sampai gagal ginjal terminal, dan jika jatuh kedalam kondisi yang berat dapat berujung pada kematian sehingga diperlukan penanganan segera (Purnomo, 2011).

Menurut peneliti, dari fakta dan teori pada penelitian ini sebagian besar responden yang mengalami BSK disebabkan karena adanya kadar kolesterol yang meningkat didalam darah akan disekresikan melalui glomerolus ginjal dan bercampur dengan air kemih. Hal ini sesuai dengan teori Purnomo (2011) menyatakan bahwa kolesterol yang terdapat dalam air kemih akan mengadakan ikatan dengan kristalkristal yang larut dalam air kemih sehingga menjadi BSK.

Berdasarkan hasil penelitian, terdapat 33 responden yang mengalami non BSK. Dimana pada kelompok responden sebagian besar mempunyai kadar kolesterol total darah normal sebanyak 20 orang $(60,6 \%)$ yang terkena non BSK/BPH.

Kolesterol merupakan bahan dasar untuk sintesis zat pregnolone yang merupakan bahan baku DHEA (dehidroepianandrosteron) yang dapat memproduksi testosteron, tetapi bila berlebihan tentunya akan terjadi penumpukan lemak pada perut yang akan menekan otot- otot seksual,mengganggu testis dan prostat (Purnomo, 2011).

Menurut peneliti, kadar kolesterol total darah tinggi hampir bukan merupakan faktor resiko untuk terkena non 
BSK/BPH. Dikarenakan proporsi yang hampir sama antara kelompok kasus dan kontrol. Hampir samanya proporsi ini kemungkinan disebabkan karena bias responden dimana sampel terbatas hanya 33 orang. Hal ini juga dikarenakan pasien BPH memiliki pola makan yang baik, di tunjang dari pemeriksaan EKG yang normal. Didukung oleh Purnomo (2011) menyatakan bahwa faktor-faktor yang mempengaruhi $\mathrm{BPH}$ selain kolesterol darah adalah latar belakang kondisi penderita misalnya usia, riwayat keluarga, obesitas, olahraga, merokok, minuman beralkohol, penyakit DM, dan aktifitas seksual.

Analisis lanjut menyimpulkan bahwa terdapat hubungan yang bermakna antara kadar kolesterol total darah dengan Batu Saluran Kemih (p-value sebesar 0,013). Responden yang mempunyai kadar kolesterol darah tinggi mempunyai peluang 4,1 kali terkena BSK dibandingkan dengan responden yang terkena non BSK/BPH $(95 \%$ CI OR 1,4;11,5), maka dapat disimpulkan ada hubungan yang signifikan atau bermakna antara kadar kolesterol total darah dengan batu saluran kemih di ruang rawat inap RSUD Provinsi NTB Tahun 2018.

Hal ini sejalan dengan penelitian yang dilakukan oleh penelitian Husnah tahun 2015 menyatakan terdapat hubungan antara kadar kolesterol darah dengan kejadian batu saluran kemih, kadar kolesterol darah tinggi 6,8 kali berisiko terjadinya batu saluran kemih.

Menurut Purnomo (2011) menyatakan adanya faktor ekstrinsik yaitu salah satu nya adalah kadar kolesterol yang meningkat didalam darah akan disekresikan melalui glomerolus ginjal dan bercampur dengan air kemih, kolesterol yang terdapat dalam air kemih akan mengadakan ikatan dengan kristalkristal yang larut dalam air kemih sehingga menjadi BSK. Dimana jika tidak segera mendapatkan terapi yang adekuat menyebabkan komplikasi. Komplikasi yang paling sering adalah berupa infeksi saluran kemih sebagai akibat adanya statis urin oleh adanya batu sampai terjadinya penurunan fungsi ginjal, yang dapat berlanjut sampai gagal ginjal terminal.

Berdasarkan teori-teori yang diuraikan di atas dan hasil penelitian bahwa masih banyak kejadian kadar kolesterol total darah tinggi dan BSK, namun kedua kejadian ini tidak selalu menjadi penyebab dari masing-masing kejadian tersebut. Jika responden mengalami kadar kolesterol total darah tinggi sebelum atau setelah BSK maka dapat menyebabkan komplikasi yang berlanjut sampai gagal ginjal terminal bahkan apabila kondisi gagal nafas tersebut tidak ditangani dengan maksimal dapat menyebabkan kematian. Meskipun kedua faktor ini sangat berkaitan, namun tidak selalu kadar kolesterol total darah tinggi dapat menyebabkan BSK begitu juga dengan BSK tidak selalu disebabkan karena kolesterol total darah tinggi karena masih banyak faktor resiko lain yang dapat menyebabkan BSK.

\section{KESIMPULAN}

Berdasarkan hasil penelitian dapat disimpulkan bahwa proporsi pasien terkena BSK sebagian besar mempunyai kadar kolesterol total darah tinggi. Sedangkan proporsi pasien terkena non BSK/BPH sebagian besar mempunyai kadar kolesterol total darah normal. Analisis lanjut menunjukkan terdapat hubungan yang signifikan atau bermakna antara kadar kolesterol total darah dengan BSK di ruang rawat inap RSUD Provinsi NTB tahun 2018. 


\section{DAFTAR PUSTAKA}

America Urologic Association (AUA). 2007. Urologic Disease in America. $\quad$ www,kidney.niddk.gov (13 November 2017)

Amin, W. (2012) Intisati Internal Audit. Rineka Cipta : Jakarta.

Arikunto, S. (2010) Prosedur Penelitian. Rineka Cipta : Jakarta.

Badan Penelitian dan Pengembangan Kesehatan Kementerian Kesehatan RI 2013, Riset Kesehatan Dasar. Bakti Husada : Jakarta.

Cooperberg, MR, Presti JC, Shonohara K, Carrol PR, 2013, Neoplasms of the prostate gland, In : Mc Aninch JW, Lue TF, Newyork.

Chang (2009). Aplikasi pada Praktik Keperawatan. Penerbit Buku Kedokteran EGC: Jakarta.

Dahlan S. M. (2010), Besar Sampel dan cara Pengambilan Sampel Dalam Penelitian Kedokteran dan Kesehatan, Salemba medika: Jakarta

Graha, K.C. (2010) Kolesterol. PT Elexmedia Computindo: Jakarta.

Gupta A, dkk. Anthropometric and metabolic factory and risk of benign prostatic hyperplasia : A prospective cohort study of Air Force veterans. Urology. Volume 68, Issue, 6December 2006, Pages 1198-1205 URL http://www.sciencedirect.com. Diakses 19 Maret 2018.

Hardjono (2008) Profil Analisis Batu Saluran Kemih di Laboratorim Patologi Klinik. Indonesia Journal of Clinical Pathology and Medical Laboratory, Vol. 12, No 3 : Makasar.

Hidayat, A. A. (2014) Metode Penelitian Keperawatan dan Teknis Analisa Data. Salemba Medika : Jakarta.
Husnah (2015), Hubungan Pola Makan dan Kadar Kolesterol Darah Dengan Batu Saluran Kemih di Poli Urologi RSUD DR. Zainoel Abidin Banda Aceh, Jurnal Kedokteran Syiah Kuala, 15 (34):421-429.

Kurniadi \& Nurrahmani (2014). Stop Diabetes Hipertensi Kolesterol Tinggi Jantung Koroner. Istana Media. 2 Yogyakarta.

Kimata, T. Kaneko K.,et al (2012) Inkreased Urinary Calcium Exkretion Kaused by Seftriaxone: Possible Assosiation With Urolitiasis. Pediatr Nephror 27 : 605-609.

Notoadmodjo, S. (2012). Metodelogi Penelitian Kesehatan. Rineka Cipta: Jakarta.

Pharos Indonesia 2012. Definisi Batu Saluran Kemih. Available www.dechacare.com Cefradoxsil.com.

Purnomo (2011) Dasar Dasar Urologi. Ke Tiga ED. Sagung Seto :Jakarta.

Satoshi H.Kidney Stone Disease and Risk Factor of CHD. International Journal of Urology . 2005.

Sugiono. (2011) Metode Penelitian Kuantitatif Kualitatif dan $R \& D$. Alfabeta : Bandung.

Suyanto. (2011), Metodologi dan Aplikasi Penelitian Keperawatan, Nuha Medika : Jakarta. 